\title{
An account of Colletotrichum species associated with strawberry anthracnose in China based on morphology and molecular data
}

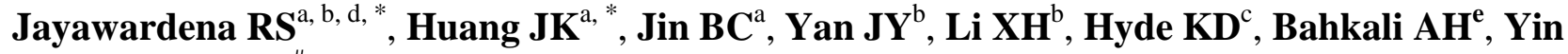 \\ $\mathbf{S L}^{\mathrm{a}}$, Zhang GZ $\mathbf{G}^{\mathrm{a}, \#}$ \\ ${ }^{a}$ College of Plant Protection, China Agricultural University, Beijing 100193, People's Republic of China \\ ${ }^{b}$ Institute of Plant and Environment Protection, Beijing Academy of Agriculture and Forestry Sciences, Beijing 100097, \\ People's Republic of China \\ ${ }^{c}$ Key Laboratory for Plant Diversity and Biogeography of East Asia, Kunming Institute of Botany, Chinese Academy of \\ Science, Kunming 650201, Yunnan, People's Republic of China \\ ${ }^{d}$ Centre of Excellence in Fungal Research, Mae Fah Luang University, Chiang Rai 57100, Thailand \\ ${ }^{e}$ Botany and Microbiology Department, College of Science, King Saud University, Riyadh, KSA 11442, Saudi Arabia
}

*These authors contributed equally to the work.

Jayawardena RS, Huang JK, Jin BC, Yan JY, Li XH, Hyde KD, Bahkali AH, Yin SL, Zhang GZ 2016 - An account of Colletotrichum species associated with strawberry anthracnose in China based on morphology and molecular data. Mycosphere 7(8) 1147-1163, Doi $10.5943 /$ mycosphere/si/2c/6

\begin{abstract}
Strawberry anthracnose is an important disease in China that results in significant economic losses. A number of Colletotrichum species are known to be pathogens of strawberry. A survey of strawberry fields in eight provinces of China was carried out to identify the causal agents of strawberry anthracnose. The disease mainly causes crown rot, leading to plant wilt and death in the nursery stage, after transplanting in green house, which makes anthracnose a major threat to strawberry production and quality. Multi-locus sequence analysis coupled with morphological assessment revealed that the disease-associated taxa belong to two Colletotrichum species complexes: Colletotrichum nymphaeae (acutatum species complex), $C$. fructicola and $C$. changpingense sp. nov. (gloeosporioides species complex). The novel species is introduced in this paper and illustrated. The new species is closely related to $C$. theobromicola and pathogenicity tests proved that it is pathogenic to the strawberry crown, fruits and leaves.
\end{abstract}

Keywords - C. nymphaeae - crown rot - molecular phylogeny - morphology - pathogen

\section{Introduction}

Strawberry (Fragariax ananassa) is a major crop cultivated in China (Xie et al. 2010). Strawberry production has expanded rapidly in recent years and China has become one of the world's largest strawberry producers and exporters. Strawberry cultivation occupies $100.5 \times 10^{3}$ ha with a yield of 2.8 million tonnes in 2013 (The Ministry of Agriculture of the People's Republic of China 2014). With the increase of production, many fungal diseases have become a major problem in strawberry production, reducing fruit yield and quality (Mass 1998, Smith 2008). One of the most important diseases of strawberry is anthracnose, which is caused by species of Colletotrichum. 
Colletotrichum is one of the most important plant pathogenic genera worldwide (Cannon et al. 2012, Hyde et al. 2014, Nilsson et al. 2014, Yan et al. 2015), occurring predominantly in tropical and subtropical regions on a wide range of crops (Waller 1993, Hyde et al. 2009 a, b, 2014). A summary of names (Hyde et al. 2009a) and a review of the confusion with names in the genus (Hyde et al. 2009b), helped to kick start a series of studies that used molecular phylogeny and morphology, that have helped to define species in the genus (Cannon et al. 2012). Anthracnose caused by Colletotrichum species is a major disease affecting strawberry production across the world (Mass 1998). Colletotrichum species infect all plant parts causing serious crown rot, irregular leaf spots, necrotic lesions on the petioles and runners, as well as black spot on the fruits (Mass 1998). Anthracnose can cause up to $80 \%$ of plant death in nurseries and over $50 \%$ of yield losses in strawberry fields (Sreenivasaprasad \& Talhinhas 2005). For successful implementation of any resistance breeding and disease management programme, accurate pathogen identification is important (Freeman et al. 1998).

Strawberry anthracnose was first reported in China as late as 1990 (Hu 1990). Shao (1992) reported strawberry anthracnose in Shanghai for the first time and identified the pathogen as $C$. acutatum (Dai et al. 2006). Zhang et al. (2007) contributed to these findings by identifying $C$. gloeosporioides and $C$. fragariae (syn $C$. theobromicola) as the causal agents based on morphological characters. Ren et al. $(2008,2011)$ concluded that these three species are the main pathogens causing anthracnose of strawberry in China. Crown rot is the most severe disease problem in most strawberry producing areas in China (Ren et al. 2008). In the Zhejiang region, nearly $50 \%$ of seedling deaths in nurseries and over $40 \%$ of yield losses in strawberry fields has been recorded (Xie et al. 2010). The yield of greenhouse cultivated strawberries was reduced by over 10\% due to crown rot in Donggang city in Laoning Province in 2009 (Wang 2013). The average incidence of crown rot in green houses of Hubei Province was 41.7\% in 2011 (Xiang et al. 2012). However, the majority of studies conducted in China regarding this disease were mainly based on morphology and single gene (mainly ITS) analysis (Dai et al. 2006, Ren et al. 2008, 2011). Due to the overlapping characters, species delimitation based on morphology alone is difficult in this genus. Use of multi-gene analysis combined with morphology can provide a better resolution (Cai et al. 2009, Hyde et al. 2014). Therefore the objective of this study was to identify the pathogens causing strawberry anthracnose in China using a morphological and multi-gene approach.

\section{Materials and Methods}

\section{Sample collection, Isolation and Identification of fungi}

Disease samples showing anthracnose symptoms were collected from different locations (Anhui, Hainan, Hebei, Hubei, Liaoning, Shandong Provinces and Beijing, Shanghai cities) in China during 2011-2014. To promote fungal development and facilitate isolation, samples were incubated in a clean polythene bag with sterilized tissue dipped in distilled water. Samples were surface sterilized in 3.5\% Sodium hypochlorite for 1-2 minutes and then rinsed three times in sterilized water before culturing on Potato Dextrose Agar (PDA) medium at $28{ }^{\circ} \mathrm{C}$. Single germinating conidia were transferred to fresh PDA medium and incubated at $28{ }^{\circ} \mathrm{C}$ to obtain pure colonies of the fungi (Chomnunti et al. 2014). The pure isolates were maintained on PDA medium with sterilized filter paper and incubated for 7-10 days at $28{ }^{\circ} \mathrm{C}$. Cultures on the filter papers were dried and stored at $-20{ }^{\circ} \mathrm{C}$ for further study. Fungal mycelia and spores were observed and photographed using a ZEISS Imager M1 microscope and measurements were made on 40 conidia. All microscopic measurements were made with the Axio vision v 4.8 and images used for figures were processed with Adobe Photoshop CS3 Extended version 10.0 software (Adobe Systems, The United States). Facesoffungi and Index Fungorum numbers are provided (Jayasiri et al. 2015, Index Fungorum 2016). 


\section{DNA extraction, PCR amplification and DNA sequencing}

Total genomic DNA was extracted by the modified protocol of Damm et al. (2008). Total genomic DNA was extracted from fresh mycelium $(500 \mathrm{mg})$, scraped from the margin of a colony on a PDA plate incubated at $28{ }^{\circ} \mathrm{C}$ for $7-10$ days. The $5.8 \mathrm{~S}$ nuclear ribosomal gene with the two flanking internal transcribed spacers (ITS), a 200-bp intron of the glyceraldehyde-3-phosphate dehydrogenase (GAPDH), partial sequences of the chitin synthase 1 (CHS-1), actin (ACT) and $\beta$ tubulin genes were amplified using primer pairs ITS1/ITS4 (White et al. 1990), GDF/GDR (Templeton et al. 1992), CHS79F/CHS345R (Carbone \& Kohn 1999), ACT512F/ACT783R (Carbone \& Kohn 1999) and BT1/BT2 (O’Donnell \& Cigelnik 1997) respectively. PCR was performed in a BIORAD 1000 Thermal Cycler in a total volume of $25 \mu \mathrm{l}$. PCR mixtures contained TaKaRa Ex-Taq DNA polymerase $0.3 \mu \mathrm{l}, 12.5 \mu \mathrm{l}$ of $2 \times$ PCR buffer with $2.5 \mu \mathrm{l}$ of dNTPs, $1 \mu \mathrm{l}$ of each primer, $9.2 \mu \mathrm{l}$ of double-distilled water and 100-500 ng of DNA template. The thermal cycling program followed that reported in Weir et al. (2012). The PCR products were visualised by staining with Ethidium bromide on $1.2 \%$ agarose electrophoresis gels and purified according to the manufacturer's instructions of a Qiagen purification kit (Qiagen, USA). DNA sequencing of the genes was conducted by Sunbiotech Company Ltd., Beijing, China. The sequence data from this study are placed in GenBank.

\section{Phylogenetic Analysis}

Consensus sequences from the sequences generated from forward and reverse primers were obtained using DNAStar v.5.1 and SeqMan v.5.00 (Burland 2000). A combined dataset of the five gene regions was prepared using Clustal X1.81 (Thompson et al. 1997). Further alignment of sequences was achieved using default settings in MAFFT v.7 (Katoh \& Toh 2008, http://mafft.cbrc.jp/alignment/server/) and manual adjustment was conducted using BioEditv.7.0.9.0 (Hall 1999) where necessary. Two separate phylogenetic trees were constructed for the acutatum species complex and for the gloeosporioides species complex. Maximum Parsimony analysis (MP) was performed using PAUP v. 4.0b10 (Swofford 2002) to obtain the most parsimonious trees. Gaps were treated as missing data and ambiguously aligned regions were excluded. Trees were inferred using the heuristic search option with Tree Bisection Reconnection (TBR) branch swapping and 1000 random sequence additions. Maxtrees were set up to 5,000, branches of zero length were collapsed and all multiple parsimonious trees were saved. Descriptive tree statistics for parsimony (Tree Length [TL], Consistency Index [CI], Retention Index [RI], Rescaled Consistency index [RC], and Homoplasy index [HI]) were calculated for trees generated under different optimality criteria. The robustness of the most parsimonious trees was evaluated by 1000 bootstrap replications resulting from maximum parsimony analysis (Hillis \& Bull 1993). Kishino-Hasegawa tests (KHT) (Kishino \& Hasegawa 1989) were performed in order to determine whether trees were significantly different.

Bayesian inference (BI) was used in addition to construct the phylogenies using Mr. Bayes v.3.1.2 (Ronquist et al. 2003). MrModeltest v. 2.3 (Nylander 2004) was used to carry out statistical selection of best-fit model of nucleotide substitution. HYK+I model was selected for ITS, a $\mathrm{HKY}+\mathrm{G}$ model for GAPDH and $\beta$-tubulin, a $\mathrm{K} 80+\mathrm{I}+\mathrm{G}$ model for $\mathrm{CHS}-1$, a GTR $+\mathrm{G}$ model for ACT were incorporated into the analysis. Six simultaneous Markov chains were run for 1000000 generations and trees were sampled every $100^{\text {th }}$ generation. The 2000 trees representing the burn-in phase of the analyses were discarded and the remaining 8000 trees used for calculating posterior probabilities (PP) in the majority rule consensus tree. The alignments and trees are deposited in TreeBASE (Sanderson et al. 1994) under accession numbers S20238 respectively. The fungal strains used for the phylogenetic analysis in this study are listed in Table 1.

\section{Genealogical concordance phylogenetic species recognition (GCPSR) analysis}

New species and their most closely related species were analysed using the GCPSR model. A pairwise homoplasy index (PHI) (Philippe \& Bryant 2006) test was performed in SplitsTree4 (Huson 1998, Huson \& Bryant 2006) as described by Quaedvlieg et al. (2014), in order to determine the recombination level within phylogenetically closely related species using a five-locus 
concatenated dataset for $C$. changpingense and its related species. If the pairwise homoplasy index is below a 0.05 threshold $\left(\Phi_{\mathrm{w}}<0.05\right)$, it indicated that there is a significant recombination present in the dataset. The relationships between closely related species were visualised by constructing a split graph, using both the LogDet transformation and splits decomposition options (Fig. 6).

\section{Pathogenicity test}

In order to test the pathogenicity of the new species, detached fruits and leaves inoculations were conducted. To determine whether this new species can infect the rhizome (crown), seedling inoculations were carried out.

\section{Detached fruits and leaves inoculation}

Healthy strawberry fruits, leaves and seedlings were used for the pathogenicity test. Fruits and leaves were surface sterilized with $75 \%$ ethanol and washed three times with distilled water. Fifteen leaves and 15 fruits per isolate were wounded by means of sterilized insect needle, while 15 leaves and 15 fruits remained non-wounded. Conidial suspension $\left(10^{5} / \mathrm{mL}\right.$, emended by a haemocytometer) was applied on the wounded and non-wounded fruits and uniformly sprayed onto the leaves. Control fruits and leaves were inoculated with sterilized water. The inoculated fruits and leaves with the controls were put into a plastic box covered with plastic film and incubated at 25 ${ }^{\circ} \mathrm{C}$.

\section{Seedling/ Rhizome inoculation}

In order to check the pathogenicity towards the strawberry rhizome, 30 strawberry seedlings planted in plastic pots were inoculated with spore suspension. Each seedling was planted in one pot and a $100 \mathrm{~mL}$ spore suspension was added. The control seedlings were inoculated with sterilized water. The inoculated seedlings and the controls were kept in a growth chamber at $25^{\circ} \mathrm{C}$ with a 12 h day/ night.

\section{Results}

\section{Isolation of fungi}

Colletotrichum species were isolated from strawberry fruits, petioles, rhizomes and stolons showing typical anthracnose symptoms (Fig. 1). One hundred and twenty-one isolates were obtained from the disease samples and are deposited in the China General Microbiological Culture Collection (CGMCC) / Mae Fah Luang University Culture Collection, Thailand (MFLUCC) and the China Agricultural University Beijing (SA), China.

\section{Phylogenetic analysis}

Twenty-one representative strains were used in the analysis. Phylogenies were reconstructed using combined ACT, GAPDH, CHS, ITS and $\beta$-tubulin sequence data for our isolates of Colletotrichum with those in recent publications on Colletotrichum (Damm et al. 2012, Weir et al. 2012, Sharma et al. 2013, Yan et al. 2015, Diao et al. 2017). A single phylogenetic tree was constructed for all Colletotrichum strains including our sequence data using five combined gene alignments. The tree was compared with the backbone tree in Hyde et al. (2014) and species narrowed down to the acutatum and gloeosporioides species complexes. Two separate phylogenetic trees were therefore constructed for the complexes. Maximum- parsimony and Bayesian inference produced nearly identical topologies (Bayesian trees are not shown).

The combined gene alignment for the acutatum complex comprised 37 taxa and 1712 characters including gaps with $C$. orchidophilum (CBS 632.80) as the outgroup taxon. Parsimony analysis indicated that 1249 characters were constant, 229 variable characters uninformative and 234 characters parsimony-informative. The parsimony analysis of the data matrix yielded a single most parsimonious tree ( $\mathrm{TL}=689, \mathrm{CI}=0.729, \mathrm{RI}=0.820, \mathrm{RC}=0.597, \mathrm{HI}=0.271$ ) which is presented in Fig 2. Five isolates (SA0017, SA0024, SA0041, SA0069 and SA0070) clustered together with $C$. nymphaeae with strong support. 


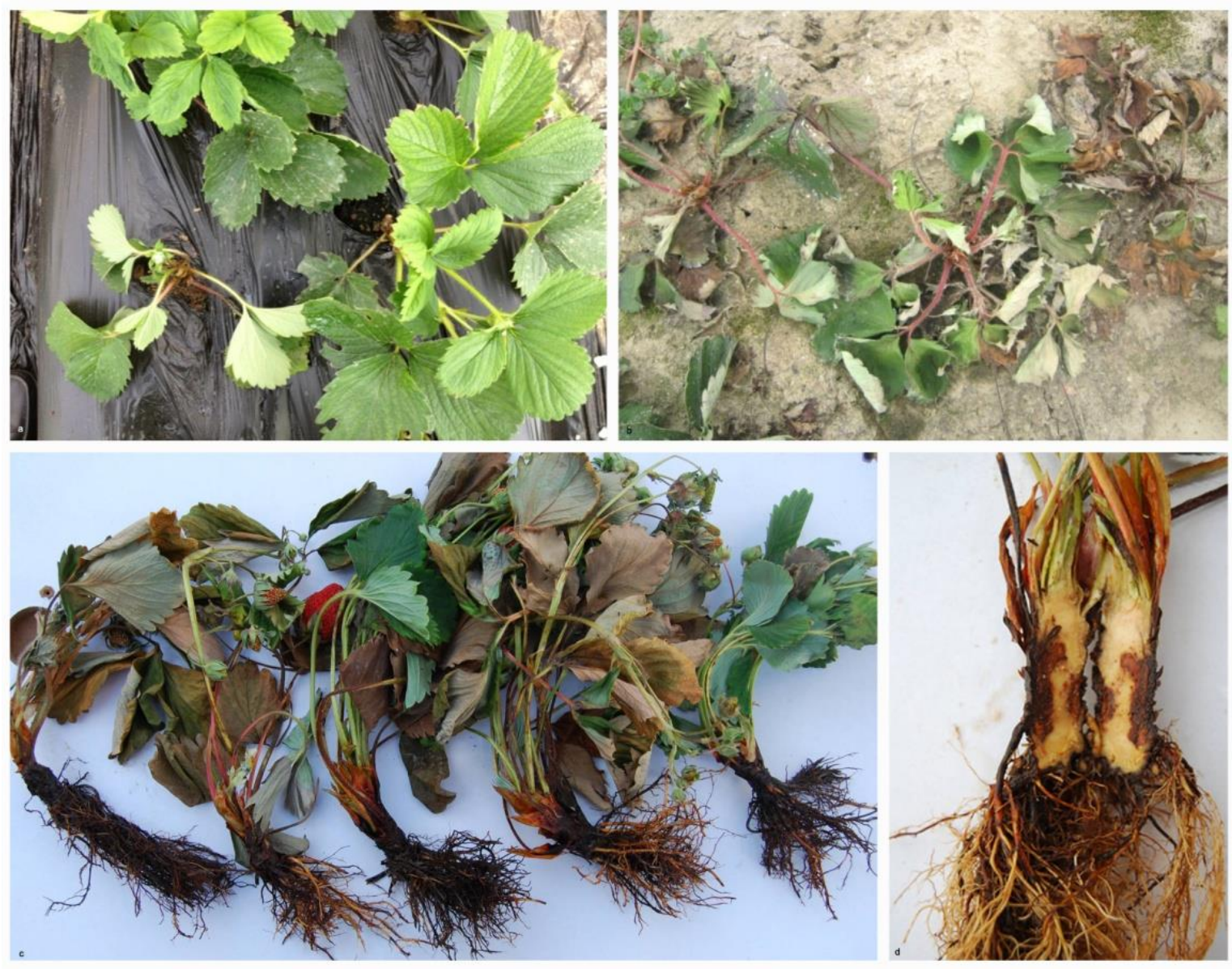

Fig. 1 - Symptoms of strawberry anthracnose a. Wilted seedling plants at early disease stage in greenhouse, b. Wilted and dead plants in the field, c. Dead plants with crown rot symptoms, d. Reddish brown tissue of a strawberry crown infected by Colletotrichum sp.

The combined gene alignment for the gloeosporioides complex comprised 52 taxa and 1932 characters including gaps with $C$. boninense (CBS 123755) as the outgroup taxon. Parsimony analysis indicated that 1350 characters were constant, 318 variable characters parsimonyuninformative and 264 characters parsimony-informative. Parsimony analysis resulted in 100 most parsimonious trees, one of them $(\mathrm{TL}=1040, \mathrm{CI}=0.696, \mathrm{RI}=0.779, \mathrm{RC}=0.542, \mathrm{HI}=0.304)$ is shown in Fig. 3 where 15 isolates obtained in this study clustered together with $C$. fructicola (CBS 130416) with a high support, while isolates SA0016 and SA0050 are sister to the clade that contains $C$. grevilleae, $C$. grossum and $C$. theobromicola also with high support (100/1.00).

\section{Pathogenicity studies}

\section{Detached fruits and leaves inoculation}

All of the inoculated leaves and fruits showed symptoms after $72 \mathrm{~h}$ inoculation. Symptoms on the wounded leaves and fruits appeared $24 \mathrm{~h}$ earlier than the non-wounded tissues. Orange spore masses appeared on the lesion under high humidity condition.

\section{Seedling inoculation}

The inoculated strawberry seedlings began wilting after $10 \mathrm{~d}$ inoculation. The wilting seedlings were stunt compared with control plants. Necrosis was observed in the roots of the wilted plants. The longitudinal section of the crown showed red brown, hard lesions in rot. Twenty-four inoculated seedlings (80\%) died after 20 d inoculation. Control seedlings remained healthy. 


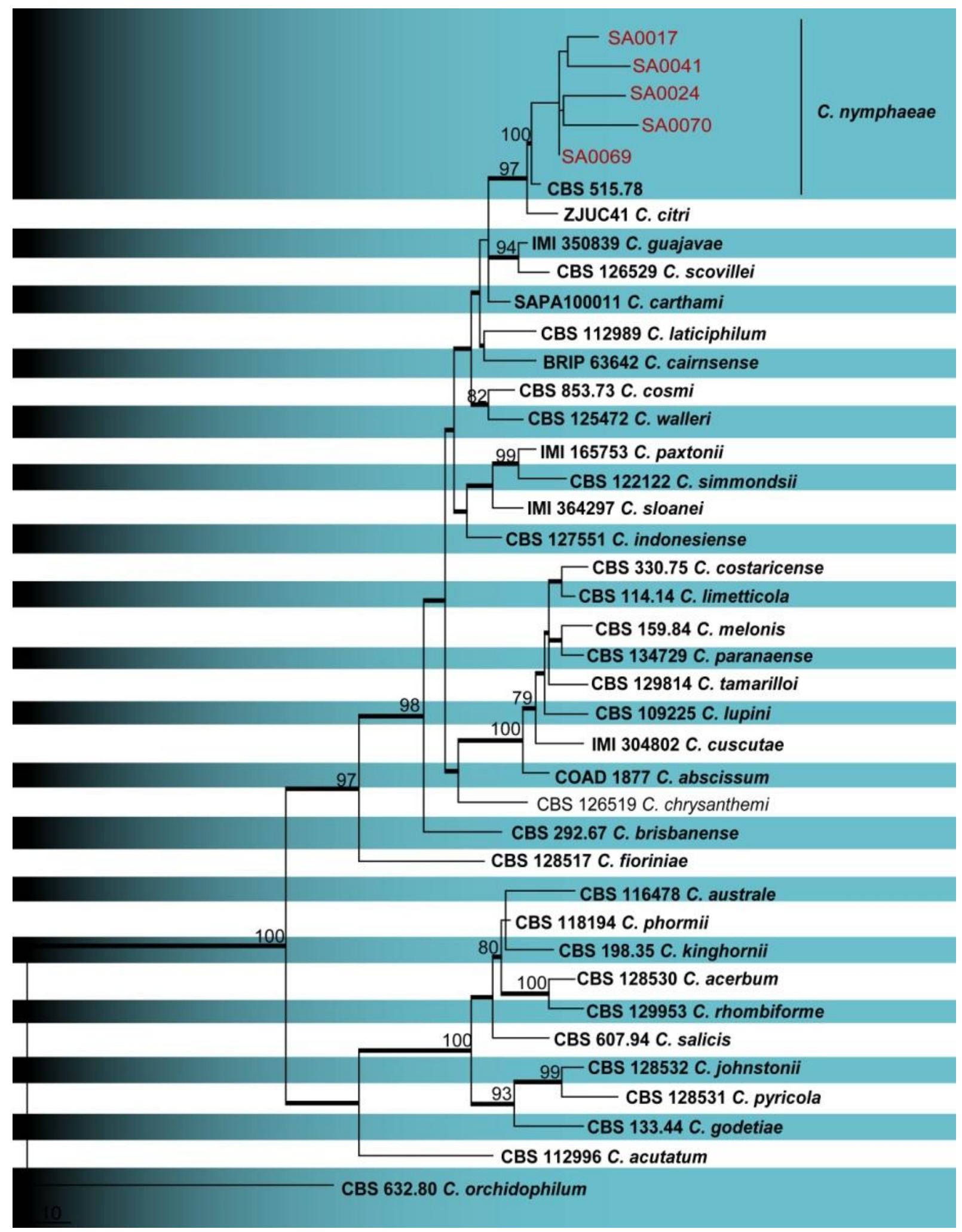

Fig. 2 - One of the 100 most parsimonious trees obtained from a heuristic search of combined ACT, GAPDH, CHS, ITS and $\beta$-tubulin sequenced data of the acutatum species complex. Parsimony bootstrap support values greater than $70 \%$ are indicated above the nodes and branches with Bayesian posterior probabilities above 0.90 are given in bold. The ex-type strains are in bold; isolates of this study are in red. The scale bar indicates ten changes. The tree is rooted with $C$. orchidophilum CBS 632.80. 


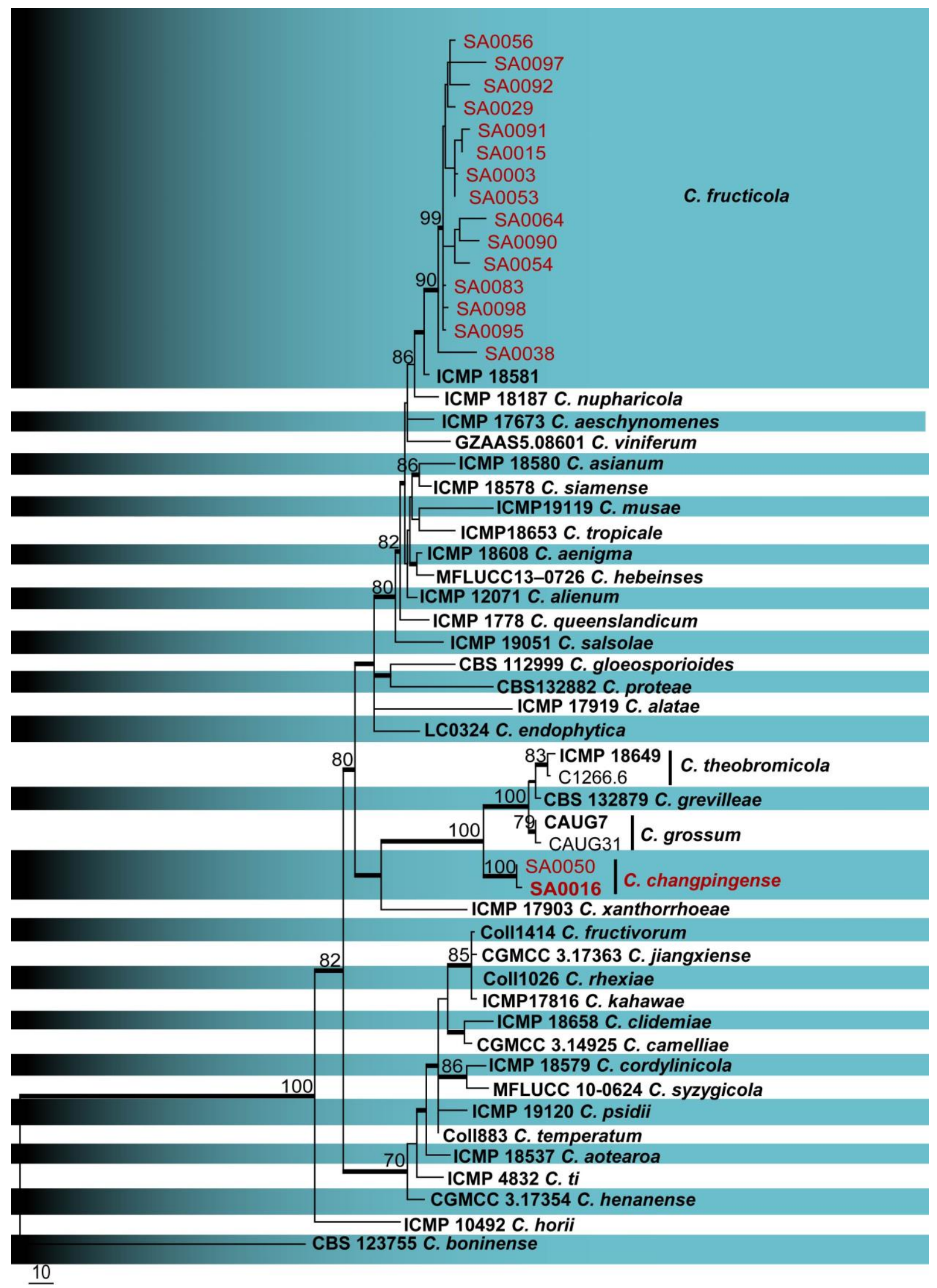

Fig. 3-One of the 100 most parsimonious trees obtained from a heuristic search of combined ACT, GAPDH, CHS, ITS and $\beta$-tubulin sequenced data of the gloeosporioides species complex. Parsimony bootstrap support values greater than $70 \%$ are indicated above the nodes and branches with Bayesian posterior probabilities above 0.90 are given in bold. The ex-type strains are in bold; isolates of this study are in red. The scale bar indicates ten changes. The tree is rooted with $C$. boninense CBS 123755. 

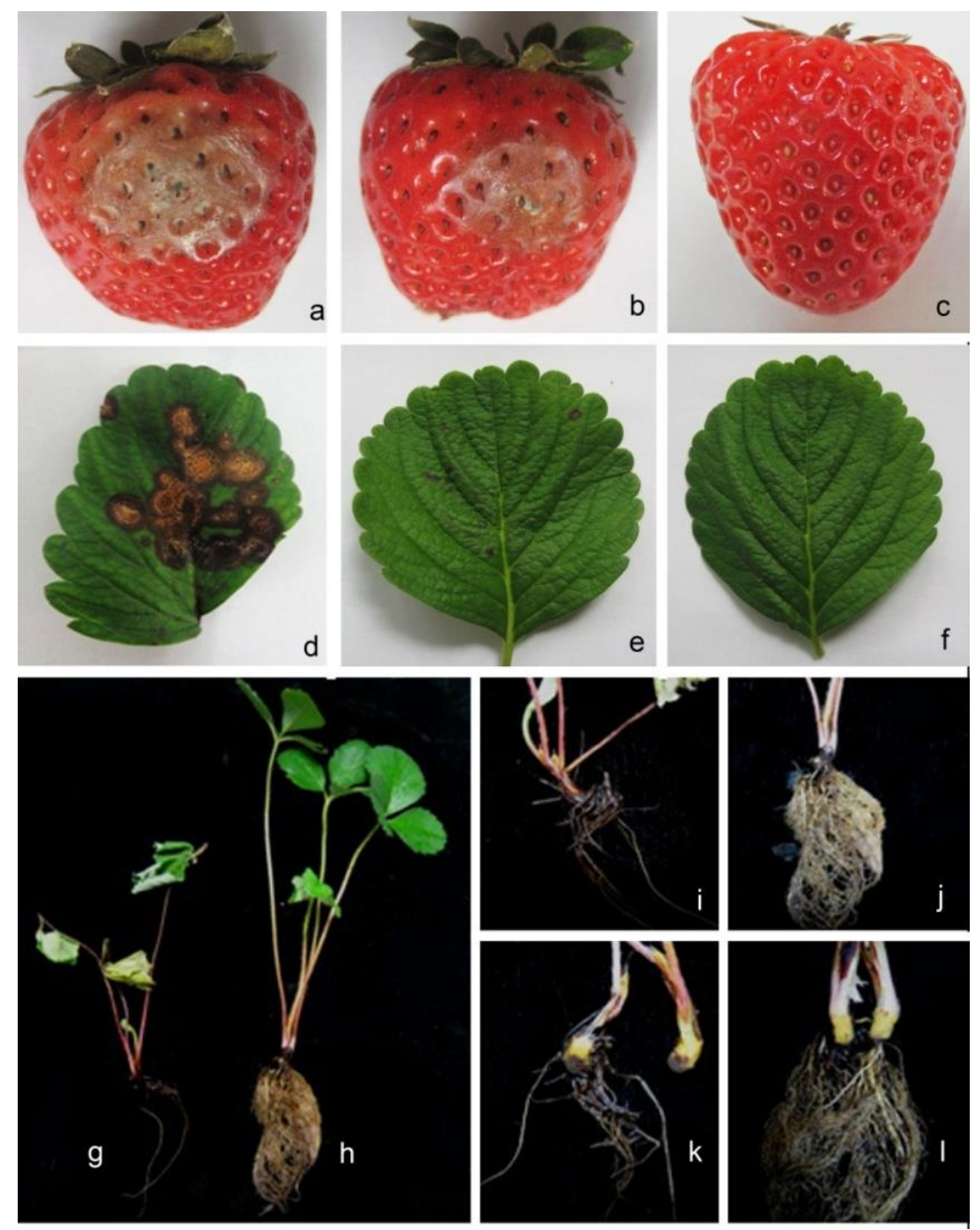

Fig. 4 - Pathogenicity test results of $C$. changpingense (SA0016). a-f. Symptoms on leaves and fruits after $80 \mathrm{~h}$ of inoculation. a, d. Wound inoculation. b-c. Non-wound inoculation. g-l. Symptoms of the seedlings and on root after 14days of inoculation. g. Seedling with reddish-brown rhizome and wilted leaves. i, k. Reddish-brown rhizome with retarded root growth. c, f, j, l. Control fruit, leaf and rhizome.

\section{Taxonomy}

Colletotrichum fructicola Prihast., L. Cai \& K.D. Hyde

Colletotrichum fructicola was originally reported from coffee berries in Thailand (Prihastuti et al. 2009) and has a wide host range (Weir et al. 2012). Colletotrichum fructicola belongs to the gloeosporioides species complex and has been reported from Canada and the USA causing strawberry anthracnose (Weir et al. 2012). Fifteen strains of this species were isolated from strawberry in this study; one strain from a fruit, two strains from petioles, 11 strains from rhizomes and one strain from a stolon. In the phylogram, our strains clustered with $C$. fructicola (ICMP 18581) with $99 \%$ bootstrap support and posterior probability values of 1.00 (Fig. 3).

\section{Colletotrichum nymphaeae (Pass.) Aa.}

A detailed description of $C$. nymphaeae was provided by Damm et al. (2012). This species has a wide host range and belongs to the acutatum species complex. Colletotrichum nymphaeae has been recorded from Bulgaria, Canada, France, Israel, Italy, Kenya, Netherlands, South Africa, Spain, Switzerland, the UK and the USA (Damm et al. 2012), where it causes strawberry anthracnose. Five strains of this species were isolated from strawberry; two from fruits, two from petioles and one from a stolon. In the phylogram, our strains clustered with $C$. nymphaeae (CBS515.78) with $100 \%$ bootstrap support and posterior probability values of 1.00 (Fig. 2). 
Colletotrichum changpingense G. Zhang, Jayawardena \& KD Hyde, sp. nov.

Index Fungorum No: IF552575; Facesoffungi number: FoF: 00644, Fig. 4

Etymology-This species is named after the locality, where this species was found.

Holotype: MFLU 15-0212

Pathogen on strawberry rhizome. Colonies growing from single conidia on PDA white, reverse black in centre, pale yellow grey towards the edge, reaching a maximum of $78 \mathrm{~mm}$ diam. in 7 days at $28{ }^{\circ} \mathrm{C}$, growth rate $2-7.8 \mathrm{~mm} /$ day. Aerial mycelium, white, dense, cottony. Vegetative hyphae 1-2.1 $\mu \mathrm{m}$ hyaline, smooth-walled, septate, branched. Asexual morph developed on PDA. Conidiomata 208-425 $\mu \mathrm{m}$ diam., abundant, black, an acervulus, oval, solitary to aggregated, with orange spore masses. Setae absent. Conidiophores $26 \mu \mathrm{m}$ long, hyaline to light brown, cylindrical or clavate, smooth-walled, simple, wide at the base, occuring in densly arranged clusters. Conidiogenous cells $7-26 \times 1.5-3(\bar{x}=18.5 \times 1.9, \mathrm{n}=10)$, enteroblastic, hyaline, smooth-walled, cyllindrical, tapering from base to apex, opening with a $0.5-1.5 \mu \mathrm{m}$ diam. collarette, $<0.5 \mu \mathrm{m}$ long, periclinal thickening conspicuous. Conidia $9-15 \times 2.5-6 \mu \mathrm{m}(\bar{x}=12.3 \times 4.6, \mathrm{n}=40)$ hyaline, smoothwalled or minutely verruculose, aseptate, ovoid to cylindrical or clavate with rounded apices, contents granular and mostly present at the polar ends leaving anopaque region in the centre. Appressoria notobserved. Sexual morph not observed.

Material examined - CHINA, Beijing City, Changping, Xingshou Town, from rhizome of Fragaria $\times$ ananassa, November 2011, Zhang Guozhen (MFLU 15-0212, holotype), ex-type living culture, SA0016 (MFLUCC 15-0022, CGMCC3.17582); CHINA, Guangzhou, from rhizome of Fragaria $\times$ ananassa, April 2012, Zhang Guozhen living culture, SA0050.
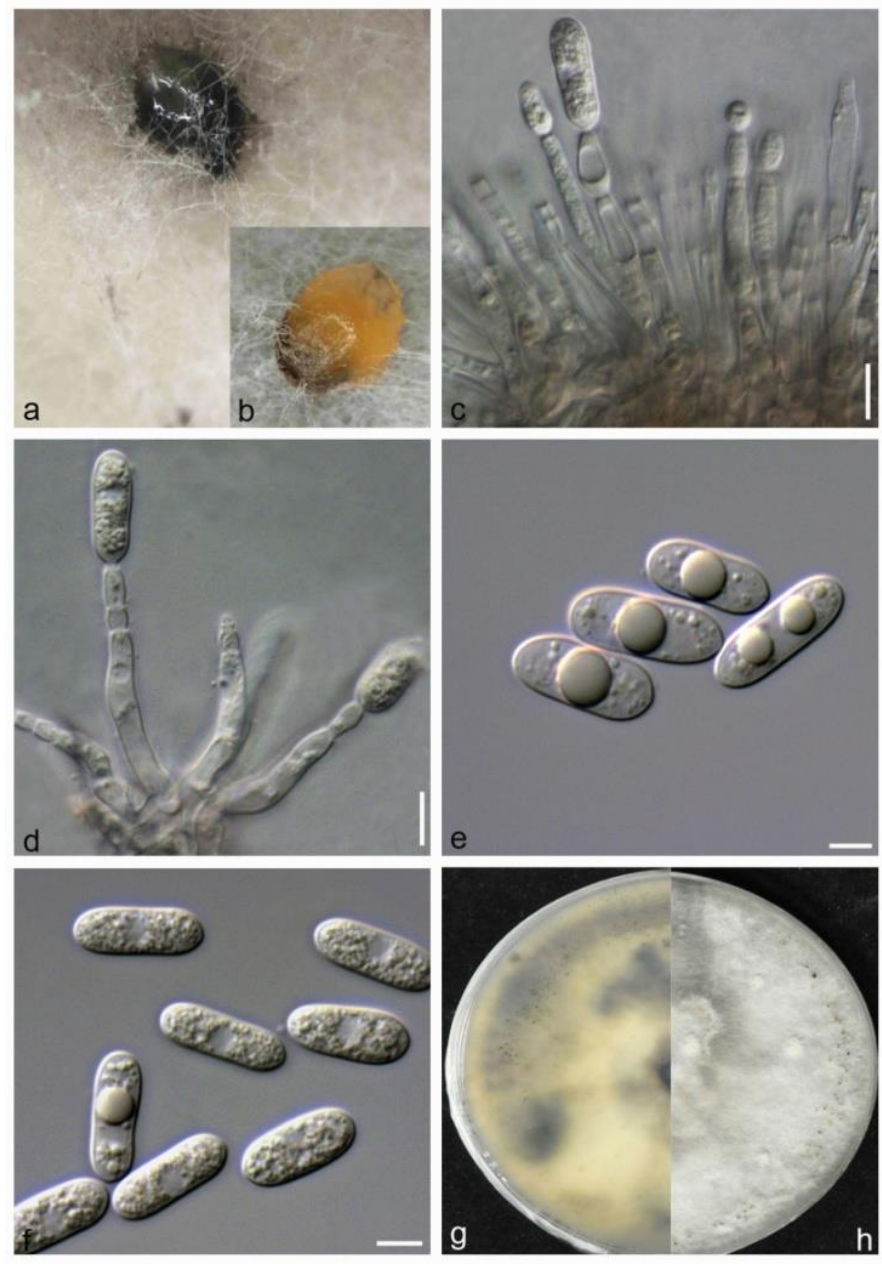

Fig. 5 - Colletotrichum changpingense (MFLUCC 15-0022, ex-type culture). a. Conidioma on PDA b. Orange coloured spore mass. c-d. Conidiogenous cells. e-f. Conidia. g. Upper view of colony $(7 \mathrm{~d}$ old $)$. $\mathrm{h}$. reverse view of colony $(7 \mathrm{~d}$ old $)$. Scale bars $=5 \mu \mathrm{m}$. 
Notes - Based on multi-locus sequence data (ACT, CHS, GAPDH, ITS and $\beta$-tubulin), $C$. changpingense is phylogenetically closely related to $C$. grevilleae, $C$. grossum and $C$. theobromicola. Sequence data derived from the ITS region does not separate $C$. changpingense from $C$. grevilleae, $C$. theobromicola and $C$. grossum. The BLASTn search with the ITS sequence of this strain showed 100\% similarity to JX573319 C. gloeosporioides isolate. The closest match in a BLASTn search in GenBank with the GAPDH sequence was JX009957 C. theobromicola strain with 99\% similarity. The closest matches in a BLASTn search in GenBank with the CHS sequence was KF772060 C. siamense strain with 97\% similarity, with the ACT sequence was KT936435 $C$. siamense strain with $99 \%$ similarity. The BLASTn search with the $\beta$-tubulin is identical to $C$. grossum (CAUG7, KP890171) and C. theobromicola (C1273, JX010382). Colletotrichum changpingense differs from the type strain of $C$. grevilleae by $17 \mathrm{bp}$ changes in ACT, $11 \mathrm{bp}$ changes in CHS, 6bp changes in GAPDH and 8bp changes in ITS. Colletotrichum changpingense differs from the type strain of $C$. theobromicola by $17 \mathrm{bp}$ changes in ACT, $12 \mathrm{bp}$ changes in CHS, $2 \mathrm{bp}$ changes in GAPDH, 9bp changes in ITS and $8 \mathrm{bp}$ changes in $\beta$-tubulin. Colletotrichum changpingense differs from the type strain of $C$. grossum by $18 \mathrm{bp}$ changes in ACT, $9 \mathrm{bp}$ changes in CHS and 5bp changes in GAPDH. Therefore C. changpingense provides sufficient data to be accommodated as a new species. A PHI test revealed no significant recombination event between C. changpingense and its closely related taxa (Fig. 6).
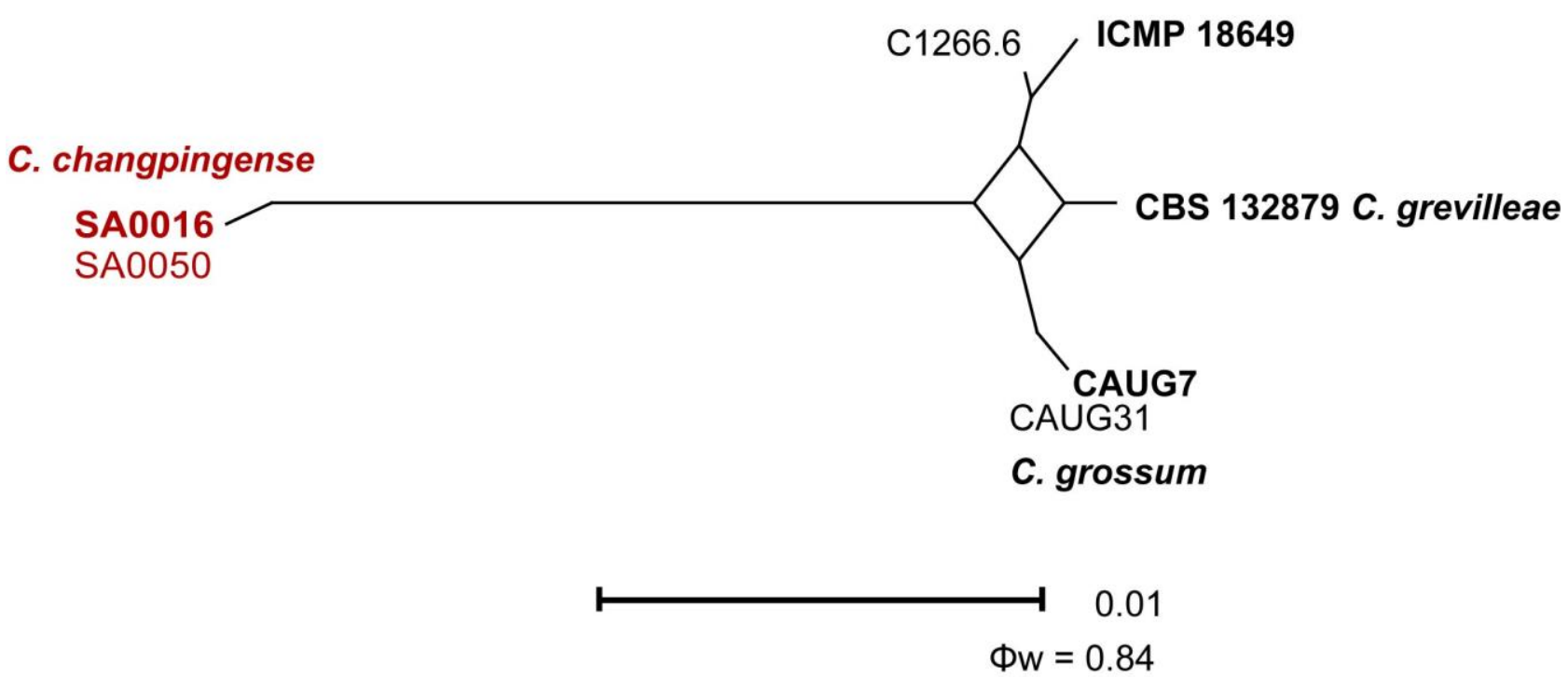

Fig. 6 - The results of the pairwise homoplasy index (PHI) test of closely related species using both LogDet transformation and splits decomposition. PHI test results $(\Phi \mathrm{w})<0.05$ indicate significant recombination within the dataset.

\section{Discussion}

Previous studies on Colletotrichum species causing strawberry anthracnose were mainly based on morphological characters and single gene based identifications, which would have been identified to species complexes rather than individual species (Ye et al. 2009). Due to the high variability in morphological characters (Sutton1992, Johnston \& Jones 1997), differentiation between two main strawberry pathogens, C. gloeosporioides and C. theobromicola (fragariae) became problematic (Ye et al. 1997, Xie et al. 2010), which led to the use of molecular methods (Cai et al. 2009) as they provide useful data in clarifying the systematics of Colletotrichum (Hyde et al. 2014, Yan et al. 2015). Xie et al. (2010) identified the Colletotrichum species causing anthracnose disease of Strawberry cv. Toyonoka in Zhejiang and Shanghai, China to be $C$. acutatum, C. gloeosporioides and C. theobromicola using morphology and ITS gene region alone. As ITS gene alone does not resolve Colletotrichum species well (Martinez-Culebras 2002, Jelev et al. 2008, Xie et al. 2010), multigene analysis has been adopted to resolve Colletotrichum species satisfactorily (Cai et al. 2009, Hyde et al. 2014), and the present study has followed this protocol. 
Table 1 List of GenBank accession numbers for the ITS, ACT, CHS-1, GAPDH and $\beta$-tubulin gene sequences of the ex-type isolates belonging to the gloeosporioides species complex, acutatum species complex and the strains used in this study with information on taxa, host and geographic location. Strains sequenced in this study are bolded.

\begin{tabular}{|c|c|c|c|c|c|c|c|c|c|}
\hline \multirow[t]{2}{*}{ Species name } & \multirow[t]{2}{*}{ Isolate number } & \multirow[t]{2}{*}{ Host } & \multirow{2}{*}{\multicolumn{2}{|c|}{ Location }} & \multicolumn{5}{|c|}{ GenBank Accession Numbers } \\
\hline & & & & & ITS & ACT & CHS-1 & GAPDH & $\beta$-tubulin \\
\hline C. acerbum & ICMP $12921^{*}$ & Malus domestica & New Zealan & & JQ948459 & JQ949780 & JQ949120 & JQ948790 & JQ950110 \\
\hline C. acutatum & CBS 112996* & Carica papaya & Australia & & JQ005776 & JQ005839 & JQ005797 & JQ948677 & JQ005860 \\
\hline C. aenigma & ICMP $18608^{*}$ & Persea americana & Israel & & JX010244 & JX009443 & JX009774 & JX010044 & JX010389 \\
\hline C. aeschynomenes & ICMP $17673^{*}$ & Aeschynomene virginica & USA & & JX010176 & JX009483 & JX009799 & JX009930 & JX010392 \\
\hline C. alatae & CBS $304.67 *$ & Dioscorea alata & India & & JX010190 & JX009471 & JX009837 & JX009990 & JX010383 \\
\hline C. alienum & ICMP 12071* & Malus domestica & New Zealan & & JX010251 & JX009572 & JX009882 & JX010028 & JX010411 \\
\hline C. aotearoa & ICMP $18537^{*}$ & Coprosma sp. & New Zealan & & JX010205 & JX009564 & JX009853 & JX010005 & JX010420 \\
\hline C. asianum & ICMP $18580^{*}$ & Coffea arabica & Thailand & & FJ972612 & JX009584 & JX009867 & JX010053 & JX010406 \\
\hline C. australe & CBS 116478* & Trachycarpus fortunei & South Africa & & JQ948455 & JQ949776 & JQ949116 & JQ948786 & JQ950106 \\
\hline C. brisbanense & CBS $292.67^{*}$ & Capsicum аппиит & Australia & & JQ948291 & JQ949612 & JQ948952 & JQ948621 & JQ949942 \\
\hline C. camelliae & CGMCC $3.14925^{*}$ & Camellia sinensis & China & & KJ955081 & KJ954782 & N.S & KJ954363 & KJ955230 \\
\hline C. cairnsense & BRIP $63642 *$ & Capsicum аппиит & Australia & & KU923672 & KU923716 & KU923710 & KU923704 & KU923688 \\
\hline C. carthami & SAPA 100011* & Carthamus tinctorium & Japan & & AB696998 & N.S & N.S & N.S & AB696992 \\
\hline C. changpingense & $\begin{array}{l}\text { SA0016 (MFLUCC } \\
\text { 15-0022*) }\end{array}$ & $\begin{array}{l}\text { Rhizome of Fragaria } \\
\times \text { ananassa }\end{array}$ & $\begin{array}{l}\text { China, } \\
\text { (Changping) }\end{array}$ & Beijing & KP683152 & KP683093 & KP852449 & KP852469 & KP852490 \\
\hline C. changpingense & SA0050 & $\begin{array}{l}\text { Rhizome of Fragaria } \times \\
\text { ananassa }\end{array}$ & China, Guan & ngzhou & KY214473 & KY214470 & KY214471 & KY214472 & KY214474 \\
\hline C. chrysanthemi & IMI $364540^{*}$ & $\begin{array}{l}\text { Chrysanthemum } \\
\text { coronarium }\end{array}$ & China & & JQ948273 & JQ949594 & JQ948934 & JQ948603 & JQ949924 \\
\hline C. citri & CBS 134233* & Citrus aurantifolia & China & & KC293581 & KC293621 & N.S & KC293741 & KC293661 \\
\hline C. communis & MTCC $11599 *$ & Mangifera sp. & India & & JQ894681 & JQ894546 & JQ894617 & JQ894632 & JQ894602 \\
\hline C. cordylinicola & ICMP $18579 *$ & Cordyline fruticosa & Thailand & & JX010226 & HM470235 & JX009864 & JX009975 & JX010440 \\
\hline C. cosmi & CBS 853.73* & Cosmos sp. & Netherlands & & JQ948274 & JQ949595 & JQ948935 & JQ948604 & JQ949925 \\
\hline C. costaricense & CBS $330.75^{*}$ & Coffea arabica & Costa Rica & & JQ948180 & JQ949501 & JQ948841 & JQ948510 & JQ949831 \\
\hline C. cuscutae & IMI 304802* & Cuscuta sp. & Dominica & & JQ948195 & JQ949516 & JQ948856 & JQ948525 & JQ949846 \\
\hline C. endophytica & MFLUCC 13-0418* & Pennisetum purpureum & Thailand & & KC633854 & KF306258 & N.S & КС 832854 & N.S \\
\hline C. fioriniae & CBS $128517^{*}$ & Fiorinia externa & USA & & JQ948292 & JQ949613 & JQ948953 & JQ948622 & JQ949943 \\
\hline C. fructicola & ICMP $18581^{*}$ & Coffea arabica & Thailand & & JX010165 & FJ907426 & JX009866 & JX010033 & JX010405 \\
\hline C. fructicola & SA0003 & $\begin{array}{l}\text { Rhizome of Fragaria } \\
\times \text { ananassa }\end{array}$ & $\begin{array}{l}\text { China, } \\
\text { (Changping) }\end{array}$ & Beijing & KР683149 & KP683090 & KP852446 & KP852466 & KP852487 \\
\hline C. fructicola & SA0015 & $\begin{array}{l}\text { Rhizome of Fragaria } \\
\text { xananassa }\end{array}$ & $\begin{array}{l}\text { China, } \\
\text { (Changping) }\end{array}$ & Beijing & KP683148 & KP683089 & KP852445 & KP852465 & KP852486 \\
\hline C. fructicola & SA0029 & $\begin{array}{l}\text { Rhizome of } \\
\text { Fragaria } \times \text { ananassa }\end{array}$ & $\begin{array}{l}\text { China, } \\
\text { (Changping) }\end{array}$ & Beijing & KP683153 & KP683094 & - & KP852470 & KP852491 \\
\hline C. fructicola & SA0038 & $\begin{array}{l}\text { Stolon of } \\
\text { Fragaria } \times \text { ananassa }\end{array}$ & $\begin{array}{l}\text { China, } \\
\text { (Changping) }\end{array}$ & Beijing & KP683151 & KP683092 & KP852448 & KP852468 & KP852489 \\
\hline C. fructicola & SA0053 & $\begin{array}{l}\text { Petiole of } \\
\text { Fragaria } \times \text { ananassa }\end{array}$ & $\begin{array}{l}\text { China, } \\
\text { (Donggang) }\end{array}$ & Liaoning & KP683150 & KP683091 & KP852447 & KP852467 & KP852488 \\
\hline C. fructicola & SA0054 & $\begin{array}{l}\text { Rhizome of } \\
\text { Fragaria } \times \text { ananassa }\end{array}$ & $\begin{array}{l}\text { China, } \\
\text { (Donggang) }\end{array}$ & Liaoning & KP683147 & KP683088 & KP852444 & KP852464 & KP852485 \\
\hline C. fructicola & SA0056 & $\begin{array}{l}\text { Rhizome of } \\
\text { Fragaria } \times \text { ananassa }\end{array}$ & $\begin{array}{l}\text { China, } \\
\text { (Shanghai) }\end{array}$ & Shanghai & KP683138 & KP683079 & KP852435 & KP852455 & KP852476 \\
\hline
\end{tabular}




\begin{tabular}{|c|c|c|c|c|c|c|c|c|}
\hline \multirow[t]{2}{*}{ Species name } & \multirow[t]{2}{*}{ Isolate number } & \multirow[t]{2}{*}{ Host } & \multirow[t]{2}{*}{ Location } & \multicolumn{5}{|c|}{ GenBank Accession Numbers } \\
\hline & & & & ITS & ACT & CHS-1 & GAPDH & $\beta$-tubulin \\
\hline C. fructicola & SA0064 & $\begin{array}{l}\text { Rhizome of } \\
\text { Fragaria } \times \text { ananassa }\end{array}$ & $\begin{array}{l}\text { China, Shandong } \\
\text { (Qingdao) }\end{array}$ & KP683139 & KP683080 & KP852436 & KP852456 & KP852477 \\
\hline C. fructicola & SA0083 & $\begin{array}{l}\text { Rhizome of } \\
\text { Fragaria } \times \text { ananassa }\end{array}$ & $\begin{array}{l}\text { China, } \\
\text { (Fangshan) }\end{array}$ & KP683143 & KP683084 & KP852440 & KP852460 & KP852481 \\
\hline C. fructicola & SA0090 & $\begin{array}{l}\text { Rhizome of } \\
\text { Fragaria } \times \text { ananassa }\end{array}$ & $\begin{array}{l}\text { China, (Changfeng), } \\
\text { Anhui }\end{array}$ & KP683142 & KP683083 & KP852439 & KP852459 & KP852480 \\
\hline C. fructicola & SA0091 & $\begin{array}{l}\text { Rhizome of } \\
\text { Fragaria } \times \text { ananassa }\end{array}$ & $\begin{array}{l}\text { China, (Changfeng), } \\
\text { Anhui }\end{array}$ & KP683145 & KP683086 & KP852442 & KP852462 & KP852483 \\
\hline C. fructicola & SA0092 & $\begin{array}{l}\text { Rhizome of } \\
\text { Fragaria } \times \text { ananassa }\end{array}$ & $\begin{array}{l}\text { China, } \\
\text { (Tongzhou) }\end{array}$ & KP683140 & KP683081 & KP852437 & KP852457 & KP852478 \\
\hline C. fructicola & SA0095 & $\begin{array}{l}\text { Rhizome of } \\
\text { Fragaria } \times \text { ananassa }\end{array}$ & $\begin{array}{l}\text { China, } \\
\text { (Wuhan) }\end{array}$ & КР683144 & KP683085 & KP852441 & KP852461 & KP852482 \\
\hline C. fructicola & SA0097 & $\begin{array}{l}\text { Petiole of } \\
\text { Fragaria } \times \text { ananassa }\end{array}$ & $\begin{array}{l}\text { China, } \\
\text { (Fangshan) }\end{array}$ & KP683141 & KP683082 & KP852438 & KP852458 & KP852479 \\
\hline C. fructicola & SA0098 & $\begin{array}{l}\text { Fruit of } \\
\text { Fragaria } \times \text { ananassa }\end{array}$ & $\begin{array}{l}\text { China, } \\
\text { (Haikou) }\end{array}$ & KР683146 & KP683087 & KP852443 & KP852463 & KP852484 \\
\hline C. fructivorum & CBS $133125^{*}$ & Vaccinium macrocarpo & USA & JX145145 & N.S & N.S & N.S & JX145196 \\
\hline C. gloeosporioides & IMI 356878* & Citrus sinensis & Italy & JX010152 & JX009531 & JX009818 & JX010056 & JX010445 \\
\hline C. grevilleae & CBS $132879^{*}$ & Grevillea sp. & Italy & KC297078 & KC296941 & KC296987 & KC297010 & KC297102 \\
\hline C. grossum & CAUG7* $*$ & Capsicum sp. & China & KP890165 & KP890141 & KP890153 & KP89015 & KP890171 \\
\hline C. godetiae & CBS $133.44 *$ & Clarkia hybrida & Denmark & JQ948402 & JQ949723 & JQ949063 & JQ948733 & JQ950053 \\
\hline C. guajavae & IMI 350839* & Psidium guajava & India & JQ948270 & JQ949591 & JQ948931 & JQ948600 & JQ949921 \\
\hline C. hebeiense & MFLUCC 13-0726* & Vitis vinifera & China & KF156863 & KF377532 & KF289008 & KF377495 & KF288975 \\
\hline C. henanense & CGMCC $3.17354 *$ & Camilla sinensis & China & KJ955109 & KM023257 & N.S & KJ954810 & KJ955257 \\
\hline C. horii & ICMP 10492* & Diospyros kaki & Japan & GQ329690 & JX009438 & JX009752 & GQ329681 & JX010450 \\
\hline C. indonesiense & CBS $127551^{*}$ & Eucalyptus sp. & Indonesia & JQ948288 & JQ949609 & JQ948949 & JQ948618 & JQ949939 \\
\hline C. jiangxiense & CGMCC $3.17363 *$ & Camilla sinensis & China & KJ955201 & KJ954471 & N.S & KJ954902 & KJ955348 \\
\hline C. johnstonii & CBS $128532 *$ & Solanum lycopersicum & New Zealand & JQ948444 & JQ949765 & JQ949105 & JQ948775 & JQ950095 \\
\hline C. kahawae & ICMP 17816* & Coffea arabica & Kenya & JX010231 & JX009452 & JX009813 & JX010012 & JX010444 \\
\hline C. kinghornii & CBS $198.35^{*}$ & Phormium sp. & UK & JQ948454 & JQ949775 & JQ949115 & JQ948785 & JQ950105 \\
\hline C. laticiphilum & CBS $112989^{*}$ & Hevea brasiliensis & India & JQ948289 & JQ949610 & JQ948950 & JQ948619 & JQ949940 \\
\hline C. limetticola & CBS 114.14* & Citrus aurantifolia & USA & JQ948193 & JQ949514 & JQ948854 & JQ948523 & JQ949844 \\
\hline C. lupine & CBS $109225^{*}$ & Lupinus albus & Ukraine & JQ948155 & JQ949476 & JQ948816 & JQ948485 & JQ949806 \\
\hline C. melonis & CBS $159.84 *$ & Cucumis melo & Brazil & JQ948194 & JQ949515 & JQ948855 & JQ948524 & JQ949845 \\
\hline C. mиsae & CBS $116870^{*}$ & Musa sp. & USA & JX010146 & JX009433 & JX009896 & JX010050 & HQ596280 \\
\hline C. nupharicola & CBS 470.96* & Nuphar lutea & USA & JX010187 & JX009437 & JX009835 & JX009972 & JX010398 \\
\hline C. nymphaeae & CBS 515.78* & Nymphaea alba & Netherlands & JQ948197 & JQ949518 & JQ948858 & JQ948527 & JQ949848 \\
\hline C. nymphaeae & SA0017 & $\begin{array}{l}\text { Petiole of } \\
\text { Fragaria } \times \text { ananassa }\end{array}$ & $\begin{array}{l}\text { China, } \\
\text { (Daxing) }\end{array}$ & КР683133 & КР683074 & KP852430 & KP852450 & KP852471 \\
\hline C. nymphaeae & SA0024 & $\begin{array}{l}\text { Petiole of } \\
\text { Fragaria } \times \text { ananassa }\end{array}$ & $\begin{array}{l}\text { China, Beijing } \\
\text { (Xiaotangshan) }\end{array}$ & KP683135 & KP683076 & KP852432 & KP852452 & KP852473 \\
\hline C. nymphaeae & SA0041 & $\begin{array}{l}\text { Fruit of } \\
\text { Fragaria } \times \text { ananassa }\end{array}$ & $\begin{array}{l}\text { China, } \\
\text { (Baoding) }\end{array}$ & КР683134 & KP683075 & KP852431 & KP852451 & KP852472 \\
\hline C. nymphaeae & SA0069 & $\begin{array}{l}\text { Fruit of } \\
\text { Fragaria } \times \text { ananassa }\end{array}$ & $\begin{array}{l}\text { China, Beijing } \\
\text { (Changping) }\end{array}$ & KР683137 & KP683078 & KP852434 & KP852454 & KP852475 \\
\hline C. nymphaeae & SA0070 & $\begin{array}{l}\text { Stolon of } \\
\text { Fragaria } \times \text { ananassa }\end{array}$ & $\begin{array}{l}\text { China, Beijing } \\
\text { (Changping) }\end{array}$ & KP683136 & KP683077 & KP852433 & KP852453 & KP852474 \\
\hline C. orchidophilum & CBS $632.80^{*}$ & Dendrobium sp. & USA & JQ948151 & JQ949472 & JQ948812 & JQ948481 & JQ949802 \\
\hline C. paranaense & CBS $134729 *$ & Malus domestica & Brazil & KC204992 & KC205077 & KC205043 & KC205026 & KC205060 \\
\hline
\end{tabular}




\begin{tabular}{|c|c|c|c|c|c|c|c|c|}
\hline \multirow[t]{2}{*}{ Species name } & \multirow[t]{2}{*}{ Isolate number } & \multirow[t]{2}{*}{ Host } & \multirow[t]{2}{*}{ Location } & \multicolumn{5}{|c|}{ GenBank Accession Numbers } \\
\hline & & & & ITS & ACT & CHS-1 & GAPDH & $\beta$-tubulin \\
\hline C. paxtonii & IMI 165753* & Musa sp. & Saint Lucia & JQ948285 & JQ949606 & JQ948946 & JQ948615 & JQ949936 \\
\hline C. phormii & CBS 118194* & Phormium sp. & Germany & JQ948446 & JQ949767 & JQ949107 & JQ948777 & JQ950097 \\
\hline C. proteae & CBS $132882 *$ & Protea sp. & South Africa & KC297079 & KC296940 & KC296986 & КС297009 & KC297101 \\
\hline C.psidii & CBS $145.29^{*}$ & Psidium sp. & Italy & JX010219 & JX009515 & JX009901 & JX009967 & JX010443 \\
\hline C. pyricola & CBS $128531 *$ & Pyrus communis & New Zealand & JQ948445 & JQ949766 & JQ949106 & JQ948776 & JQ950096 \\
\hline C. queenslandicum & ICMP 1778* & Carica papaya & Australia & JX010276 & JX009447 & JX009899 & JX009934 & JX010414 \\
\hline C. rhexiae & CBS 133134* & Rhexia virginica & USA & JX145128 & N.S & N.S & N.S & JX145179 \\
\hline C. rhombiforme & CBS 129953* & Olea europaea & Portugal & JQ948457 & JQ949778 & JQ949118 & JQ948788 & JQ950108 \\
\hline C. salicis & CBS 607.94* & Salix sp. & Netherlands & JQ948460 & JQ949781 & JQ949121 & JQ948791 & JQ950111 \\
\hline C. salsolae & ICMP $19051 *$ & Salsola tragus & Hungary & JX010242 & JX009562 & JX009863 & JX009916 & JX010403 \\
\hline C. scovillei & CBS $126529^{*}$ & Capsicum sp. & Indonesia & JQ948267 & JQ949588 & JQ948928 & JQ948597 & JQ949918 \\
\hline C. siamense & ICMP $18578^{*}$ & Coffea arabica & Thailand & JX010171 & FJ907423 & JX009865 & JX009924 & JX010404 \\
\hline C. simmondsii & CBS $122122 *$ & Carica papaya & Australia & JQ948276 & JQ949597 & JQ948937 & JQ948606 & JQ949927 \\
\hline C. sloanei & IMI 364297* & Theobroma cacao & Malaysia & JQ948287 & JQ949608 & JQ948948 & JQ948617 & JQ949938 \\
\hline C. syzygicola & MFLUCC* & Syzygium samarangense & Thailand & KF242094 & KF157801 & N.S & KF242156 & KF254880 \\
\hline & $10-0624$ & & & & & & & \\
\hline C. temperatum & CBS $133122 *$ & Vaccinium macrocarpon & USA & JX145159 & N.S & N.S & N.S & JX145211 \\
\hline C. tamarilloi & CBS 129814* & Solanum betaceum & Colombia & JQ948184 & JQ949505 & JQ948845 & JQ948514 & JQ949835 \\
\hline C. theobromicola & CBS $124945^{*}$ & Theobroma cacao & Panama & JX010294 & JX009444 & JX009869 & JX010006 & JX010447 \\
\hline C. $t i$ & ICMP 4832* & Cordyline sp. & New Zealand & JX010269 & JX009520 & JX009898 & JX009952 & JX010442 \\
\hline C. tropicale & CBS 124943* & Theobroma cacao & Panama & JX010264 & JX009489 & JX009870 & JX010007 & JX010407 \\
\hline C. truncatum & CBS $151.35^{*}$ & Phaseolus lunatus & USA & GU227862 & GU227960 & GU228352 & GU228254 & N.S \\
\hline C. viniferum & GZAAS5.08601* & Vitis vinifera & China & JN412804 & JN412795 & N.S & JN412798 & JN412813 \\
\hline C. walleri & CBS 125472* & Coffea sp. & Vietnam & JQ948275 & JQ949596 & JQ948936 & JQ948605 & JQ949926 \\
\hline C. xanthorrhoeae & ICMP $17903^{*}$ & Xanthorrhoea preissii & Australia & JX010261 & JX009478 & JX009823 & JX009927 & JX010448 \\
\hline
\end{tabular}

[*Abbreviation: CBS Culture Collection of the Centraalbureau voor Schimmelcultures, Fungal Biodiversity Centre, Utrecht, The Netherlands; CGMCC: China General

Microbiological Culture Collection, China; GZAAS Guizhou Academy of Agricultural Sciences herbarium, China; ICMP International Collection ofMicroorganisms from Plants,

Landcare Research, Auckland, New Zealand; IMI: Culture collection of CABI Europe UK Centre, Egham, UK; MFLUCC: Mae Fah Luang University Culture Collection, Thailand;

SA Culture collection of China Agriculture University, Beijing, China; N.S. not sequenced 
The main taxa reported to cause strawberry anthracnose worldwide are $C$. acutatum, $C$. gloeosporioides and C. fragariae (Mass 1998), the latter which has been synonimized under $C$. theobromicola (Weir et al. 2012). Besides C. acutatum, C. gloeosporioides and C. theobromicola, C. coccodes (Buddie et al. 1999; Cannon et al. 2012), C. cuscutae (Damm et al. 2012), C. fructicola (Weir et al. 2012), C. fioriniae (MacKenzie et al. 2009; Damm et al. 2012), C.godetiae (Damm et al. 2012), C. nymphaeae (Damm et al. 2012), C. salicis (Damm et al. 2012) and C. simmondsii (Whitelaw-Weckertet al. 2007, Damm et al. 2012) have been reported to be associated with strawberry anthracnose; most of these taxa belong to $C$. acutatum species complex.

In this study, we have determined the species of Colletotrichum that are associated with strawberry anthracnose in eight strawberry growing provinces of China. A new Colletotrichum species that causes strawberry anthracnose in China is described as $C$. changpingense, based on morphological features, multi-gene phylogenetic analysis and pathogenicity assays. The five gene multi-loci analysis revealed that this isolate from rhizomes, clustered separately from other Colletotrichum species. Pathogenicity testing showed that the newly introduced species is pathogenic not only on the strawberry crowns, but also on fruits and leaves. This species is capable of causing crown rot disease which is characterized by reddish brown rhizomes with less roots and wilted leaves. Anthracnose lesions on ripe strawberry fruits are firm, slightly sunken and covered with pink masses. This species is also capable of causing leaf spots on strawberry characterized by brown to black necrotic spots along the veins and inter-vein regions. Fifteen strains of $C$. fructicola were recorded from a fruit, petioles, rhizomes and a stolon and five strains of $C$. nymphaeae were also recorded from fruits, petioles and a stolon. As the latter two species are well-known pathogens causing strawberry anthracnose in different countries (Damm et al. 2012, Weir et al. 2012), this paper further contributes that these two species are also associated with strawberry anthracnose in China. In this study we did not find $C$. theobromicola. However, there were 15 more isolates in the single phylogenetic tree which consisted of all the Colletotrichum species that were not wellresolved. Further clarifications of those isolates are needed. This study contributes in updating the Colletotrichum species associated with strawberry of China. Species with similar morphology may have a considerable physiological and pathogenic variation. It is important to know the host distribution of a particular Colletotrichum species which will be important in implementing biosecurity measures in quarantine (Jayawardena et al. 2016).

\section{Acknowledgments}

The research was funded by special fund for Agro-scientific research in the public interest (201003064). Kevin D. Hyde thanks the Chinese Academy of Sciences, project number 2013T2S0030, for the award of Visiting Professorship for Senior International Scientists at Kunming Institute of Botany. The authors extend their sincere appreciations to the Deanship of Scientific Research at King Saud University for funding this Prolific Research group (PRG-143609).

\section{References}

Buddie AG, Martínez-Culebras P, Bridge PD, García MD, Querol A, Cannon PF, Monte E. - 1999 Molecular characterisation of Colletotrichum strains derived from strawberry. Mycological Research 103, 385-394.

Burland TG. - 2000 DNASTAR's Lasergene sequence analysis software. Methods in Molecular Biology 132, 71-91.

Cai L, Hyde KD, Taylor PWJ, Weir BS, Waller J, Abang MM, Zhang JZ, Yang YL, Phoulivong S, Liu ZY, Prihastuti H, Shivas RG, McKenzie EHC, Johnston PR. 2009 - A polyphasic approach for studying Colletotrichum. Fungal Diversity 39, 183-204.

Cannon PF, Damm U, Johnston PR, Weir BS. 2012- Colletotrichum-current status and future directions. Studies in Mycology 73, 181-213. 
Carbone I, Kohn LM.1999 - A method for designing primer sets for speciation studies in filamentous ascomycetes. Mycologia 91, 553-556.

Chomnunti P, Hongsanan S, Aguirre-Hudson B, Tian Q, Peršoh D, Dhami MK, Alias AS, Xu J-C, Liu X-Z, Stadler M, Hyde KD. 2014- The sooty moulds. Fungal Diversity 66, 1-36.

Dai FM, Ren XJ, Lu JP. 2006- First report of anthracnose fruit rot of strawberry caused by Colletotrichum acutatum in China. Plant Disease 90, p1460.

Damm U, Mostert L, Crous PW, Fourie PH. 2008 - Novel Phaeoacremonium species associated with necrotic wood of Prunus trees. Persoonia 20, 87-102.

Damm U, Cannon PF, Woundenberg JHC, Crous PW. 2012 - The Colletotrichum acutatum species complex. Studies in Mycology 73, 37-113.

Diao YZ, Zhang C, Liu F, Wang WZ, Cai L, Liu XL. 2017 - Colletotrichum species causing anthracnose disease of chili in China. Persoonia 38, 20-37.

Freeman S, Katan T, Shabi E. 1998 - Characterization of Colletotrichum species responsible for anthracnose disease of various fruits. Plant Disease 82, 596-605.

Hall TA.1999 - BioEdit: a user-friendly biological sequence alignment editor and analysis program for Windows 95/98/NT. Nucleic Acids Symposium Series 41, 95-98.

Hillis DM, Bull JJ. 1993 - An empirical test of bootstrapping as a method for assessing confidence in phylogenetic analysis. Systematic Biology 42, p182.

Hu S.1990 - The preliminary investigation of strawberry diseases. Collected abstracts for Fifth Meeting of East China, Chinese Society for Plant Pathology, Jiangsu 58-59.

Huson DH, Bryant D. 2006 - Application of phylogenetic networks in evolutionary studies. Molecular Biology and Evolution 23, 254-267.

Huson DH. 1998 - Splits Tree: analyzing and visualizing evolutionary data. Bioinformatics 14, 6873.

Hyde KD, Cai L, Cannon PF, Crouch JA, Crous PW, Damm U, Goodwin PH, Chen H, Johnston PR, Jones EBG, Liu ZY, McKenzie EHC, Moriwaki J, Noireung P, Pennycook SR, Pfenning LH, Prihastuti H, Sato T, Shivas RG, Tan YP, Taylor PWJ, Weir BS, Yang YL, Zhang JZ. 2009a - Colletotrichum names in current use. Fungal Diversity 39, 147-182.

Hyde KD, Cai L, McKenzie EHC, Yang YL, Zhang JZ, Prihastuti H. 2009b - Colletotrichum: a catalogue of confusion. Fungal Diversity 39, 1-17.

Hyde KD, Nilsson RH, Alias SA, Ariyawansa HA, Blair JE, Cai L, de Cock AWAM, Dissanayake AJ, Glockling SL, Goonasekara ID, Gorczak M, Hahn M, Jayawardena RS, van Kan JAL, Laurence MH, Lévesque CA, Li XH, Liu JK, Maharachchikumbura SSN, Manamgoda DS, Martin FN, McKenzie EHC, McTaggart AR, Mortimer PE, Nair PVR, Pawłowska J, Rintoul TL, Shivas RG, Spies CFJ, Summerell BA, Taylor PWJ, Terhem RB, Udayanga D, Vaghefi N, Walther G, Wilk M, Wrzosek M, Xu JC, Yan JY, Zhou N. 2014 - One stop shop: backbones trees for important pytopathogenic genera: I Fungal Diversity 67, 21-125.

Index Fungorum, 2016. http://www.indexfungorum.org/names/names.asp

Jayasiri SC, Hyde KD, Abd-Elsalam KA, Abdel-Wahab MA,Ariyawansa HA, Bhat J, Buyck B, Dai YC, Ertz D, Hidayat I, Jeewon R, Jones EBG, Karunarathna SC, Kirk P, Lei C, Liu JK, Maharachchikumbura SSN, McKenzie E, Ghobad-Nejhad M, Nilsson H, Pang KL, Phookamsak R, Rollins AW, Romero AI,Stephenson S, Suetrong S, Tsui CKM, Vizzini A, Wen TC, De Silva NI, Promputtha I, Kang JC. 2015 - The faces of fungi database:fungal names linked with morphology, molecular and human attributes. Fungal Diversity 74, 18357.

Jayawardena RS, Hyde KD, Jeewon R, Liu XH, Liu M, Yan JY. 2016 - Why it is important to correctly name Colletotrichum species? Mycosphere (This issue- http://doi 10.5943/mycosphere/si/1c/1).

Jelev ZJ, Bobev SG, Minz D, Maymon M, Freeman S. 2008 - First report of anthracnose fruit rot caused by Colletotrichum acutatum on pepper and tomato in Bulgaria. Plant Disease 92, pp172. 
Johnston RP, Jones D. 1997 - Relationships among Colletotrichum isolates from fruit-rots assessed using rDNA sequences. Mycologia 89, 420-430.

Katoh K, Toh H.2008 - Recent developments in the MAFFT multiple sequence alignment program. Briefings in Bioinformatics 9, 276-285.

Kishino H, Hasegawa M. 1989 - Evaluation of the maximum likelihood estimate of the evolutionary tree topologies from DNA sequence data. Journal of Molecular Evolution 29, $170-179$.

Mass JL. 1998 - Compendium of strawberry diseases $2^{\text {nd }}$ U.S. Department of Agriculture Beltsville, Maryland. APS Press.

Mackenzie SJ, Mertely JC, Seijo TE, Peres NA. 2009 - Colletotrichum fragariaeis a pathogen on hosts other than strawberry. Plant Disease 92, 1432-1438.

Martinez-Culebras PV, Barrio E, Suarez- Fernandes MB, Gracia Lopez MD, Querol A. 2002 RAPD analysis of Colletotrichum species isolated from strawberry and the design of specific primers for the identification of $C$. fragariae. Journal of Phytopathology 150, 680 686.

Nilsson RH, Hyde KD, Pawlowska J, Ryberg M, Tedersoo L, Aas AB, Alias SA, Alves A, Anderson CL, Antonelli A, Arnold AE, Bahnmann B, Bahram M, Bengtsson-Palme J, Berlin A, Branco S, Chomnunti P, Dissanayake A, Drenkhan R, Friberg H, Frøslev TG, Halwachs B, Hartmann M, Henricot B, Jayawardena R, Jumpponen A, Kauserud H, Koskela S, Kulik T, Liimatainen K, Lindahl BD, Lindner D, Liu JK, Maharachchikumbura S, Manamgoda D, Martinsson S, Neves MA, Niskane T, Pereira OL, Pinho DB, Porter TM, Queloz V, Riit T, Sánchez-García M, de Sousa F, Stefańczyk E, Tadych M, Takamatsu S, Tian Q, Udayanga D, Unterseher M, Wang Z, Wikee S, Yan J, Larsson E, Larsson KH. Kõljalg U, Abarenkov K. 2014 - Improving ITS sequence data for identification of plant pathogenic fungi. Fungal Diversity67, 11-19.

Nylander JAA. 2004 - MrModeltest 2.0. Program distributed author. Evolutionary Biology Centre, Uppsala University.

O’Donnell K, Cigelnik E. 1997 - Two divergent intragenomic rDNA ITS2 types within a monophyletic lineage of the fungus Fusarium are nonorthologous. Molecular Phylogeny and Evolution 7, 103-116.

Philippe H, Bryant D. 2006 - A simple and robust statistical test for detecting the presence of recombination. Genetics 172, 2665-2681.

Quaedvlieg W, Binder M, Groenewald JZ, Summerell BA, Carnegie AJ, Burgess TI, Crous PW. 2014 - Introducing the consolidated species concept to resolve species in the Teratosphaeriaceae. Persoonia 33, 1-40.

Ren HY, Jiang GH, Fang L, Zhang YC, Yang XF, Miao LX, Wang HR. 2011 - Identification and biological characteristics of pathogens of strawberry anthracnose in Jiangsu province. Acta Agriculturae Zhejiangensis 23, 937-941.

Ren XJ, Liang Y, Lu JP, Yang BR, Xu JY, Dai FM. 2008 - Identification of Colletotrichum species from strawberry in Shanghai. Acta Phytopathologica Sinica 38, 325-328.

Ronquist F, Huelsenbeck JP. 2003 - MrBayes 3: Bayesian phylogenetic inference under mixed models. Bioinformatics 19, p1572.

Sanderson MJ, Donoghue MJ, Piel W, Eriksson T. 1994 - TreeBase: A prototype database of phylogenetic analyses and an interactive tool for browsing the phylogeny of life. The Journal of the Botany American 81: article 6.

Shao XH. 1992 - New disease of strawberry: Strawberry anthracnose. Acta Agriculturae Shanghai 8, 86-87.

Sharma G, Pinnaka AK, Shenoy BD. 2013 - Resolving the Colletotrichum siamense species complex using ApMat marker. Fungal Diversity 61, 117-138.

Smith BJ. 2008 - Epidemiology and pathology strawberry anthracnose: A North American perspective. HortScience 43, 69-73. 
Sreenivasaprasad S, Talhinhas P. 2005 - Genotypic and phenotypic diversity in Colletotrichum acutatum, a cosmopolitan pathogen causing anthracnose on a wide range of hosts. Molecular Plant Pathology 6, 361-378.

Sutton BC. 1992 - The genus Glomerella and its anamorph Colletotrichum. In: Colletotrichum Biology, Pathology and Control (Bailey JA, Jeger MJ, eds). CAB International, Wallingford: $1-26$.

Swofford DL. 2002 - PAUP* 4.0: phylogenetic analysis using parsimony (* and other methods). Sinauer Associates, Sunderland.

Templeton MD, Rikkerink EHA, Solon SL, Crowhurst RN. 1992 - Cloning and molecular characterization of the glyceraldehyde-3-phosphate dehydrogenase encoding gene and cDNA from the plant pathogenic fungus Glomerella cingulata. Gene 122, 225-230.

The Ministry of Agriculture of the People's Republic of China, 2013 - China Agriculture Statistical Report [M] ISBN978-7-109-19711-4, Beijing: China Agriculture Press, 2014, pp3.

Thompson JD, Gibson TJ, Plewniak F, Jeanmougin F, Higgins DG. 1997 - The Clustal X windows interface: flexible strategies for multiple sequence alignment aided by quality analysis tools. Nucleic Acids Research 24, 4876-4882.

Waller JM, Bridge PD, Black R, Hakiza G. 1993 - Characterisation of the coffee berry disease pathogen, Colletotrichum kahawae sp. nov. Mycological Research 97, 989-994.

Wang CH. 2013 - Occurrence and control of strawberry anthracnose in Donggangarea. Northen Fruit. 2, p38.

Weir B, Johnston PR, Damm U. 2012 - The Colletotrichum gloeosporioides species complex. Studies in Mycology 73, 115-180.

White TJ, Bruns T, Lee S, Taylor JW. 1990 - Amplification and direct sequencing of fungal ribosomal RNA genes for phylogenetics. In: Innis MA, Gelfand DH, Sninsky JJ, White TJ (eds) PCR protocols: a guide to methods and applications. Academic, New York, pp 315322.

Whitelaw-Weckert MA, Curtin SJ, Huang R, Steel CC, Blanchard CL, Roffey PE. 2007 Phylogenetic relationships and pathogenicity of Colletotrichum acutatum isolates from grape in subtropical Australia. Plant Pathology 56, 448-463.

Xiang FY, Han YC, Zeng XG, Zhang P, Wu RL, Feng XM, Gu YC. 2012 - A survey on the strawberry anthracnose disease in Hubei Province . Journal of Hubei Agricultural Sciences $51,5650-5653$.

Xie L, Zhang J-Z Wan Y, Hu D-W. 2010 - Identification of Colletotrichum spp. isolated from strawberry in Zhejiang province and Shanghai city, China. Journal of Zhejiang UniversitySCIENCE B (Biomedicine \& Biotechnology) 11, 61-70.

Yan JY, Jayawardena MMRS, Goonasekara I, Wang Y, Zhang W, Liu M, Yan H, Huang JB, Wang ZY, Shang JJ, Peng YL, Bahkali A, Hyde KD, Li XH. 2015 - Diverse species of Colletotrichum associated with grapevine anthracnose in China. Fungal Diversity 71, 233246.

Ye ZW, Zheng HQ, Tong YM. 1997 - First report on species of strawberry anthracnose pathogen in Shanghai suburbs and resistance of some strawberry cultivars to anthracnose. Acta agriculturae Shanghai 13, 75-80.

Zhang HY, Zhang MH, Liu ZH, Yu HB, Wang DL. 2007 - Identification and biological characteristics of Colletotrichum gloeosporioides on strawberry. Journal of Shenyang Agricultural University 38, 317-321. 